\title{
Inhibition of Human Megakaryocytopoiesis In Vitro by Platelet Factor 4 (PF4) and a Synthetic COOH-Terminal PF4 Peptide
}

\author{
Alan M. Gewirtz, ${ }^{\star \neq 5}$ Bruno Calabretta, ${ }^{\ddagger}$ Boguslaw Rucinski," Stefan Niewiarowski," ${ }^{\mathbf{1}}$ and Wen Yu Xu' \\ Departments of *Medicine, ${ }^{\ddagger}$ Pathology, ${ }^{\S}$ Physiology, and "Thrombosis Research, Temple University School of Medicine, Philadelphia, \\ Pennsylvania 19140; and the 'Department of Immunology, Second Shanghai Medical University, Shanghai, China
}

\begin{abstract}
We report that highly purified human platelet factor 4 (PF4) inhibits human megakaryocytopoiesis in vitro. At $\geq 25 \mu \mathrm{g} / \mathrm{ml}$, PF4 inhibited megakaryocyte colony formation $\sim 80 \%$ in unstimulated cultures, and $\sim 58 \%$ in cultures containing recombinant human IL 3 and granulocyte-macrophage colony-stimulating factor. Because PF4 (25 $\mu \mathrm{g} / \mathrm{ml})$ had no effect on either myeloid or erythroid colony formation lineage specificity of this effect was suggested. A synthetic COOH-terminal PF4 peptide of 24 , but not 13 residues, also inhibited megakaryocyte colony formation, whereas a synthetic 18 -residue $\beta$ thromboglobulin ( $\beta$-TG) peptide and native $\beta$-TG had no such effect when assayed at similar concentrations. The mechanism of PF4-mediated inhibition was investigated. First, we enumerated total cell number, and examined cell maturation in control colonies $(n=200)$ and colonies $(n=100)$ that arose in PF4-containing cultures. Total cells per colony did not differ dramatically in the two groups $(6.1 \pm 3.0$ vs. $4.2 \pm 1.6$, respectively), but the numbers of mature large cells per colony was significantly decreased in the presence of PF4 when compared with controls $(1.6 \pm 1.5$ vs. $3.9 \pm 2.3 ; P<0.001)$. Second, by using the human leukemia cell line HEL as a model for primitive megakaryocytic cells, we studied the effect of PF4 on cell doubling time, on the expression of both growth-regulated $\left(\mathrm{H3}, \mathrm{p53}, \mathrm{c}-\mathrm{myc}\right.$, and c-myb), and non-growth-regulated $\left(\beta_{2^{-}}\right.$ microglobulin) genes. At high concentrations of native PF4 (50 $\mu \mathrm{g} / \mathrm{ml}$ ), no effect on cell doubling time, or $\mathrm{H3}$ or p53 expression was discerned. In contrast, c-myc and c-myb were both upregulated. These results suggested the PF4 inhibited colony formation by impeding cell maturation, as opposed to cell proliferation, perhaps by inducing expression of $c-m y c$ and $c-m y b$. The ability of PF4 to inhibit a normal cell maturation function was then tested. Megakaryocytes were incubated in synthetic PF4, or $\beta$-TG peptides for $18 \mathrm{~h}$ and effect on Factor $V$ steadystate mRNA levels was determined in 600 individual cells by in situ hybridization. $\beta$-TG peptide had no effect on FV mRNA levels, whereas a $\sim 60 \%$ decrease in expression of Factor $V$ mRNA was found in megakaryocytes exposed to $\geq 100 \mathrm{ng} / \mathrm{ml}$ synthetic COOH-terminal PF4 peptide. Accordingly, PF4 modulates megakaryocyte maturation in vitro, and may func-
\end{abstract}

Address reprint requests to Dr. Alan M. Gewirtz, Thrombosis Research Center, Temple University School of Medicine, 3400 N. Broad Street, Philadelphia, PA 19140.

Received for publication 15 April 1988 and in revised form 13 December 1988.

J. Clin. Invest.

(c) The American Society for Clinical Investigation, Inc. $0021-9738 / 89 / 05 / 1477 / 10 \$ 2.00$

Volume 83, May 1989, 1477-1486 tion as a negative autocrine regulator of human megakaryocytopoiesis.

\section{Introduction}

Human megakaryocytopoiesis is a complex, highly regulated process whose study has been greatly facilitated by the advent of in vitro culture systems (1). With this tool, the existence of several positive, though not necessarily lineage specific, growth-enhancing molecules has been demonstrated. Such proliferation and/or maturation promoting activities include megakaryocyte colony-stimulating factor (Meg-CSF) ${ }^{1}$ (2), granulocyte-macrophage colony-stimulating factor (GM-CSF) (3), IL 3 (4), thrombopoietin (TPO) $(5,6)$, megakaryocyte stimulatory factor (MSF) $(7,8)$, and erythropoietin (9).

Potential inhibitors of megakaryocytopoiesis have been less well studied. Immunocytes, and their products, have been documented to cause clinically significant suppression of megakaryocyte production $(10,11)$, but the role of such cells in the day-to-day regulation of megakaryocyte development and platelet release remains speculative (12). Several groups have provided evidence that megakaryocyte colony growth is inferior in serum when compared with growth in platelet-poor plasma (13-15) suggesting that platelet constituents can inhibit megakaryocytopoiesis in vitro. Studies from our group have shown that megakaryocyte products have a similar capability $(16,17)$. These observations raise the possibility that human megakaryocytopoiesis may also be under the control of feedback or negative autocrine regulators.

The nature of the putative megakaryocyte/platelet constituent(s) involved in this form of autoregulation remains poorly defined. It has recently been reported that transforming growth factor- $\beta$ (TGF- $\beta$ ) inhibits megakaryocytopoiesis in vitro (18-20). However, because TGF- $\beta$ is widely distributed, is not known to be synthesized by megakaryocytes, and inhibits the growth of many other hematopoietic cell lineages, the physiologic relevance of this observation remains unclear (18). An incompletely characterized $12-17-\mathrm{kD}$ secreted platelet glycoprotein has also been identified as an autocrine regulator (21).

Platelet factor 4 (PF4) is a megakaryocyte/platelet-specific $\alpha$ granule protein. In the granule it exists as a tetramer, composed of identical $7,800-\mathrm{kD}$ monomers $(22,23)$. When platelets are activated, the protein is extruded from the $\alpha$ granule complexed with a high-molecular weight proteoglycan (24). Subsequently, the complex is rapidly cleared from the circula-

1. Abbreviations used in this paper: $\beta$-TG, $\beta$-thromboglobulin; FV, Factor $\mathrm{V}$ gene probe; GM-CSF, granulocyte-macrophage colony-stimulating factor; Meg-CSF, megakaryocyte colony-stimulating factor; MNC, mononuclear cells; PF4, platelet factor 4; TGF, transforming growth factor; TPO, thrombopoietin. 
tion, perhaps by binding of the protein to endothelial surfaces and hepatocytes (25).

A number of biological activities have been attributed to PF4. It neutralizes heparin (26), has the ability to stimulate leukocyte elastase activity (27) and inhibit collagenase activity (28), and is chemotactic for neutrophils, monocytes, and fibroblasts $(21,29)$. It has been postulated that the heparin binding activity (30) and the chemotactic activity (31) reside in the carboxy-terminal domain of the molecule. It has also recently been demonstrated that PF4 binds via a specific receptor to platelets (32), and that the protein has potent immunoregulatory activity $(33,34)$. The latter consists of an apparent ability to either impair $\mathrm{T}$ suppressor cell activity, or to render $\mathrm{T}$ helper cells unresponsive to the effects of $\mathrm{T}$ suppressor cells. Because PF4 can modulate $T$ cell function, and because $T$ cells have been implicated in the regulation of marrow megakaryocytopoiesis (10-12), we theorized that $\mathrm{T}$ cell-PF4 interactions could play a role in regulating marrow megakaryocyte production. To test this hypothesis, we studied the effect of highly purified PF4, and two synthetic COOH-terminal domain PF4 peptides on human megakaryocytopoiesis in vitro. We report herein molecular and cellular studies that identify this alpha granule protein as a candidate autocrine regulator of human megakaryocytopoiesis in vitro.

\section{Methods}

\section{Cells and tissue culture methods}

Hematopoietic progenitor cell assays. Megakaryocyte colonies were cloned in plasma clots $(11,12,35)$ from either unseparated light-density marrow mononuclear cells (MNC), or MNC depleted of adherent monocyte-macrophages (MO), and T lymphocytes (12). Final cell culture volumes, and target cell concentrations $\left(2 \times 10^{5} / \mathrm{ml}\right)$ were equivalent in all cases. Cultures were supplemented with normal human $A B$ serum ( $30 \% \mathrm{vol} / \mathrm{vol})$ derived from the platelet-poor plasma of a single donor. Two culture assays were used. One was designed to emulate basal marrow growth conditions and therefore contained only the normal AB serum. No other hematopoietic growth factors were added to these cultures. The other culture system was of the stimulated type. These cultures were supplemented with recombinant human (rH) IL 3 $(\sim 20 \mathrm{U} / \mathrm{ml})$ and $\mathrm{rH} \mathrm{GM}-\mathrm{CSF}(\sim 5 \mathrm{ng} / \mathrm{ml})$ (the kind gift of Dr. Steven Clark, Genetics Institute, Cambridge, MA) in addition to the normal AB serum.

Megakaryocyte colonies were enumerated by indirect immunofluorescence $(11,12)$ using a highly specific rabbit anti-human platelet glycoprotein antiserum. A cluster of three or more intensely fluorescent cells was defined as one colony. Unless otherwise stated, all data are reported as the mean \pm SEM of colonies enumerated.

Megakaryocytes in colonies were defined as small immature cells, if (a) their greatest diameter did not exceed $10 \mu \mathrm{m}$ as measured with an optical fylar (Präzision aus Jenna, GDR), (b) if they possessed a nuclear/cytoplasmic ratio similar to that of lymphocytes and/or other undifferentiated mononuclear cells in the clot, and $(c)$ if no nuclear lobation was present when viewed under phase conditions. Large mature megakaryocytes in colonies were defined as cells which $(a)$ had diameter $>10 \mu \mathrm{m},(b)$ had a lower nuclear/cytoplasmic ratio than that used to characterize small cells, or $(c)$ had identifiable nuclear lobation under fluorescent or phase microscopy.

CFU-E- (colony forming unit-erythroid) derived colony growth was stimulated by either aplastic anemia serum, or recombinant human erythropoietin (Amgen Corp., Thousand Oaks, CA). Colonyforming unit granulocyte-macrophage- (CFU-GM) derived colonies were stimulated by IL 3 and GM-CSF. Colonies were identified as previously described (11).
Isolation of mature marrow megakaryocytes. Mature (morphologically recognizable) megakaryocytes were isolated from the marrow of normal bone marrow donors by the process of counterflow centrifugal elutriation as previously described $(37,38)$. Such cells were then used for culture, or suspended in supplemented alpha medium containing $5 \%$ normal human AB serum (derived from the platelet-poor plasma of a single donor) and subjected to short term culture either in the presence or absence of varying amounts of synthetic long $\mathrm{COOH}$-terminal PF4 peptide, or $\beta$-TG peptide (see below). After culture, cells were fixed in $4 \%$ paraformaldehyde, and stored in $70 \%$ ethanol at $4^{\circ} \mathrm{C}$ for use in in situ hybridizations (see below).

$H E L$ cell line. The continuous human erythroleukemia cell line HEL (39) was kindly supplied by Dr. Thalia Papayanapoulou, University of Washington, Seattle, WA. The line was maintained in RPMI 1640 containing 10\% heat inactivated FCS (Hyclone Laboratories, Denver, CO).

\section{Molecular analysis methods}

Isolation of RNA. Total cellular RNA was purified from cells as previously described (40). In brief, cells were homogenized in a blender (Waring Products Division, Dynamics Corp. of America, New Hartford, CT) in nucleic acid extraction buffer $(75 \mathrm{mM} \mathrm{NaCl}, 20 \mathrm{mM}$ EDTA, $10 \mathrm{mM}$ Tris- $\mathrm{HCl}, \mathrm{pH} 8.0$, and $0.2 \%$ SDS), and mixed $1: 1$ with buffer-saturated phenol. The aqueous phase was recovered by centrifugation, reextracted with an equal volume of phenol and chloroform isoamyl alcohol (25:24:1), and finally with chloroform/isoamyl alcohol (24:1). Nucleic acids were precipitated with $2.5 \mathrm{vol}$ of ethanol, and DNA was removed by treatment with DNase I and precipitation with 3 $M$ sodium acetate ( $\mathrm{pH}$ 5.5). The integrity and amount of RNA samples were monitored by ethidium bromide staining of agarose-formaldehyde gels.

Northern analysis and in situ hybridization procedures. For Northern analysis, total cellular RNA was denatured with $6.6 \%$ formaldehyde and $50 \%$ formamide. RNA was then size fractionated on $1.2 \%$ agarose gel containing $6.6 \%$ formaldehyde. Blotting of RNA to nitrocellulose was carried out as described by Thomas (41). DNA probes were labeled at high specific activity by random priming essentially as described by Feinberg and Vogelstein (42). Prehybridization, hybridization, and posthybridization washes were done essentially as described by Wahl et al. (43). Autoradiography was performed by exposing filters on $\mathrm{x}$-ray film (Eastman-Kodak) at $-70^{\circ} \mathrm{C}$ using intensifying screens.

In situ hybridization was performed using a synthesis of the techniques described by Brigati et al. (44), Lum (45), and Singer et al. (46). Human megakaryocytes, fixed and stored as described above, were deposited onto glass slides by cytocentrifugation $(500 \mathrm{rpm}$ for $8 \mathrm{~min}$, Cytocentrifuge II; Shandon Southern, Sewickley, PA). Prehybridization washes, including treatment with acetic anhydride $(0.1 \%$ in triethanolamine), were carried out as described (45). Hybridization was carried out using DNA probes oligolabeled with biotin-11-dUTP (Bethesda Research Laboratories [BRL], Gaithersburg, MD) using the method of Feinberg and Vogelstein (42). $25 \mu$ l of hybridization cocktail (Amersco, Solon, $\mathrm{OH}$ ) containing $100 \mathrm{ng} / \mathrm{ml}$ of probe in $45 \%$ formamide was layered over the specimen which was then covered with a glass slide, sealed in parafilm, and then hybridized for $\sim 18 \mathrm{~h}$ at $37^{\circ} \mathrm{C}$. Posthybridization washes were carried out as described by Lum (45), the final wash being carried out in $0.16 \%$ SSC at room temperature. DNA-RNA hybrids were detected by the addition of a streptavidinbiotin-alkaline phosphatase conjugate that catalyzed the hydrolysis of the chromogens nitroblue tetrazolium and 5-bromo-4-chloro-3-indoylphosphate (DNA detection kit; BRL, Gaithersburg, MD). Positive reactions consisted of a purple-to-deep brown-colored precipitate in the cell's cytoplasm. The degree of hybridization correlates directly with the amount of precipitate accumulated in the cell.

Hybridization with pBR322 was carried out as a negative control. An additional control consisted of pretreating specimens with RNase A $(500 \mu \mathrm{g} / \mathrm{ml})$ before hybridization with the probe of interest. Hybrid- 
ization with a cDNA coding for human $\beta$ actin was used as a positive control.

Reactions were semiquantitated by computer assisted microspectrophotometry (Zonax; Carl Zeiss, Mineola, NY) as a function of light transmission through the object cell. The photometer was standardized so that light transmission through a clear area of the slide containing no cells (background) was defined as $100 \%$ transmission, whereas no light falling on the photometer was defined as $0 \%$ transmission. Identical gain and high voltage setting were used throughout. Because increasing amount of hybridization correlates directly with the density of dye accumulation in a given cell, and increasing dye accumulation impedes light transmission through any given cell being examined, it follows that those cells that allow the greatest degree of light transmission are expressing the least amount of message.

Plasmids. Plasmids containing the cDNA inserts used as probes in these experiments have been previously described. pUC9 carrying the human coagulation Factor V (FV) gene probe was the kind gift of Dr. William Kane, University of Washington, Seattle, WA (47). pBR322 was obtained from the American Type Culture Collection (Rockville, $\mathrm{MD})$. pFO 422 carrying a human histone $\mathrm{H} 3$ probe was the kind gift of Dr. G. Stein (48). Plasmids containing human c-myc (49), and a human $\beta_{2}$ microglobulin (50) gene probes were kindly supplied by $\mathrm{Dr}$. K. Soprano, Department of Microbiology, Temple University School of Medicine. Dr. Renato Baserga and Dr. Edward Mercer (Department of Pathology, Temple University Medical School) kindly supplied plasmids containing human p53 cDNA (51) and $\beta$-actin (52) inserts, respectively. Dr. F. Mavilio (Wistar Institute, Philadelphia, PA) kindly supplied a human c-myb probe (53).

Preparation of PF4 and $\beta-T G$ : synthesis of synthetic $\mathrm{COOH}$-terminal PF4 and $\beta-T G$ peptides. Human PF4 was purified essentially as published (54) using heparin-agarose affinity chromatography. Fractions eluted from the columns were pooled and then stored lyophilized. Such preparations gave a single band on SDS-polyacrylamide gels, and were judged to $>95 \%$ pure.

Native, highly purified $\beta$-TG was the kind gift of Dr. Duncan Pepper, Scottish National Blood Transfusion Service, Aberdeen, Scotland.

Synthetic PF4 and $\beta$-TG peptides were commercially synthesized and purified (Peninsula Laboratories, Belmont, CA). Purity and sequence were confirmed by the Macromolecular Analysis and Synthesis Laboratory, Temple University School of Medicine, by Edman degradation using Applied Biosciences instrumentation. The PF4 peptides used consisted of either the terminal 13 (amino acid residues 58-70), or terminal 24 amino acids (residues 47-70) in the 70-amino acid human PF4 sequence. They were designated short and long PF4 peptide, respectively. The $\beta$-TG peptide consisted of the terminal 18 amino acid residues (residues 68-85).

PF4, $\beta$-TG, and synthetic peptides were added to the cultures dissolved in alpha medium $(0.5-1.0 \mu \mathrm{g} / \mu \mathrm{l})$, replacing an equal volume of unsupplemented alpha medium so that final culture volumes in all cases were equal.

Statistical analysis. Statistical significance of differences between groups was tested using a two-tailed $t$ test.

\section{Results}

Effect of purified PF4 and $\beta-T G$ on in vitro megakaryocytopoiesis. To determine if PF4 could modify megakaryocyte colony formation in vitro, we first added various amounts of purified human PF4 to unseparated marrow MNC. To emulate basal growth conditions in marrow, the cultures contained no exogenous source of growth factors, and were supplemented only with normal human AB serum derived from platelet-poor plasma. Five experiments of this type were performed, with a total of 18 dishes per condition. In the control plates, which contained no PF4, a mean of $11 \pm 1( \pm \mathrm{SD})$ colonies per $2 \times 10^{5} \mathrm{MNC}$ plated were enumerated. In the presence of $2.5 \mu \mathrm{g} / \mathrm{ml}$ of PF $4,7 \pm 3$ colonies were counted, but this decrement was not significant $(P=0.163)$. In contrast, when PF4 was added to the cultures at a final concentration of $25 \mu \mathrm{g} / \mathrm{ml}$, $5 \pm 3$ colonies were enumerated, a $55 \%$ decrease that was highly significant $(P=0.007)$.

We then asked if the results obtained were mediated indirectly as a result of PF4-T lymphocyte interactions. To address this question, we compared the numbers of megakaryocyte colonies arising in cultures of adherent monocyte and $\mathrm{T}$ lymphocyte-depleted marrow mononuclear cells $\left(\mathrm{A}^{-} \mathrm{T}^{-} \mathrm{MNC}\right)$, with colonies arising in $\mathrm{A}^{-} \mathrm{T}^{-} \mathrm{MNC}$ to which had been added either autologous Leu $3^{+}$helper (T4), or Leu $2^{+}$and (T8) suppressor $\mathrm{T}$ cells alone, or in combination with native PF4 at concentrations of 2.5 or $25 \mu \mathrm{g} / \mathrm{ml}$ (Table I). Coculturing target cells with either nonactivated helper, or suppressor cells, with or without low concentrations $(2.5 \mu \mathrm{g} / \mathrm{ml})$ of PF4, had no significant effect on megakaryocyte colony formation when compared to growth of target cells alone. However, the addition of high concentration of PF4 $(25 \mu \mathrm{g} / \mathrm{ml})$ resulted in a highly significant decrement in colony formation, regardless of the lymphocyte subtype that was added to the cultures (Table I).

The results recorded in Table I suggested that the colony suppressive effect of PF4 was independent of its effects on T lymphocytes, and might have been exerted directly on the megakaryocyte colony forming cells. This hypothesis was tested by culturing $\mathrm{A}^{-} \mathrm{T}^{-} \mathrm{MNC}$ with purified human PF4 under simulated basal marrow growth conditions (Fig. $1 A$ ).

Table I. Effect of Coculturing Human Megakaryocyte Progenitor Cells and T Lymphocyte Subsets in the Presence of Different Amounts of Highly Purified PF4

\begin{tabular}{|c|c|c|c|c|c|c|c|}
\hline Study no. & Control (C) cells* & $\begin{array}{l}\mathrm{C} / \mathrm{T} 4 \\
(2: 1)^{\ddagger}\end{array}$ & $\begin{array}{c}\mathrm{C} / \mathrm{T} 4 \\
(2: 1) \\
+2.5 \mu \mathrm{g} / \mathrm{ml} \text { PF4 }\end{array}$ & $\begin{array}{c}\mathrm{C} / \mathrm{T} 4 \\
(2: 1) \\
+25 \mu \mathrm{g} / \mathrm{ml} \mathrm{PF4}\end{array}$ & $\begin{array}{l}\text { C/T8 } \\
(2: 1)\end{array}$ & $\begin{array}{c}\mathrm{C} / \mathrm{T} 8 \\
(2: 1) \\
+2.5 \mu \mathrm{g} / \mathrm{ml} \mathrm{PF4}\end{array}$ & $\begin{array}{c}\mathrm{C} / \mathrm{T} 8 \\
(2: 1) \\
+25 \mu \mathrm{g} / \mathrm{ml} \mathrm{PF} 4\end{array}$ \\
\hline 1 & $7 \pm 2^{\ddagger}$ & $11 \pm 0$ & $8 \pm 1$ & $-\S$ & $6 \pm 1$ & $18 \pm 2$ & - \\
\hline 2 & $11 \pm 3$ & $10 \pm 0$ & - & - & - & $7 \pm 2$ & $1 \pm 0^{\prime \prime}$ \\
\hline 3 & $116 \pm 3$ & $141 \pm 22$ & $122 \pm 29$ & $8 \pm 1^{11}$ & $163 \pm 13$ & $87 \pm 15^{\prime \prime}$ & $13 \pm 2^{\prime \prime}$ \\
\hline 4 & $33 \pm 6$ & $39 \pm 4$ & - & $3 \pm 1^{\| \prime}$ & - & $33 \pm 4$ & $3 \pm 1^{11}$ \\
\hline
\end{tabular}

Light-density marrow MNC were depleted of adherent monocyte-macrophages and T lymphocytes. They were then cloned in plasma clots $\left(2 \times 10^{5} / \mathrm{ml}\right)$ with autologous T lymphocyte subsets, in the presence of varing amounts of purified PF4 as described in Methods. Megakaryocyte colonies were enumerated in situ by indirect immunofluorescence. * Monocyte-macrophage and lymphocyte-depleted marrow MNC (2 $\times 10^{5} / \mathrm{ml}$ ). ${ }^{\ddagger}$ Ratio of control cells to $\mathrm{T}$ lymphocytes. Mean \pm SEM of colonies enumerated in quadruplicate culture plates. ${ }^{\S}$ Not tested. $\| P<0.05$. 

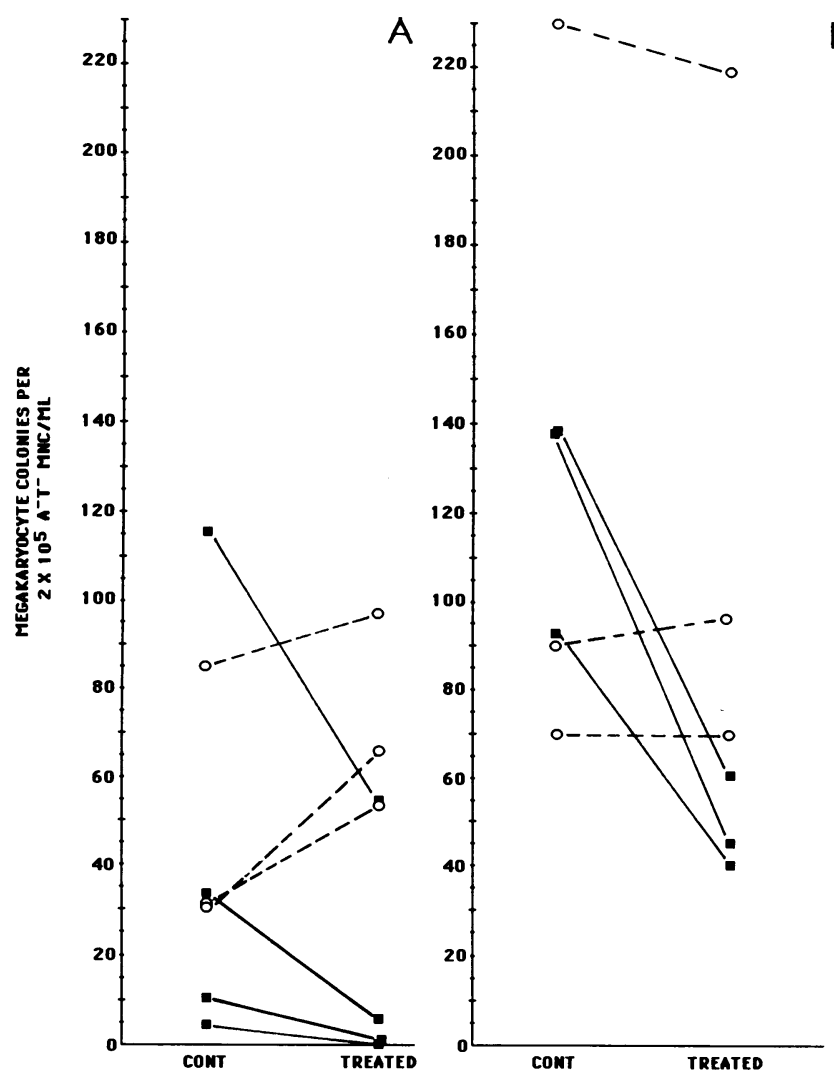

Figure 1. Effect of highly purified PF4 ( $(\mathbf{)})$, and $\beta$-TG (o) on clonogenicity of normal human megakaryocyte progenitor cells in the absence of accessory marrow immunocytes. Bone marrow MNC were isolated by density gradient sedimentation, and then depleted of adherent monocyte-macrophages, and $\mathrm{T}$ lymphocytes as detailed in Methods. PF4 or $\beta$-TG $(25 \mu \mathrm{g} / \mathrm{ml})$ was added to suspensions of the partially purified progenitor cells $\left(2 \times 10^{5} / \mathrm{ml}\right)$ that were then cultured in plasma clots in the $(A)$ absence or $(B)$ presence of recombinant human IL $3(\sim 20 \mathrm{U} / \mathrm{ml})$ and GM-CSF $(\sim 5 \mathrm{ng} / \mathrm{ml})$. Each line represents the result of a single experiment performed in duplicate or quadruplicate culture plates. Exact colony counts (mean $\pm \mathrm{SD}$ ) in the control and PF4-treated experiments ( $\square$ ) were from top to bottom respectively: $116.0 \pm 22$ vs. $53.5 \pm 7.8(P=0.064) ; 33.3 \pm 12.7$ vs. $5.5 \pm 2.1$ $(P=0.044) ; 10.5 \pm 5.7$ vs. $2.2 \pm 1.0(P=0.030) ; 5.0 \pm 1.8$ vs. $0.25 \pm 0.5$ $(P=0.002)$. In $B$, one PF4 experiment was carried out with native protein (139 \pm 11 [control] vs. $62 \pm 3$ [treated]), $P=0.010$; the other two experiments were carried out with long PF4 peptide $(25 \mu \mathrm{g} / \mathrm{ml})$. Colony counts in these studies were $138.8 \pm 22.4$ vs. $68.8 \pm 7.6(P$ $=0.001) ; 92.8 \pm 21.9$ vs. $46.5 \pm 1.0(P=0.048)$.

PF4 consistently inhibited megakaryocyte colony formation when added to cultures at concentrations of $25 \mu \mathrm{g} / \mathrm{ml}$. The mean inhibition was $\sim 78 \%$, and was statistically significant $(P<0.05)$ in three of the four experiments performed. The effect of highly purified $\beta$-TG $(25 \mu \mathrm{g} / \mathrm{ml})$ was also examined in the same system. $\beta$-TG was ideal for this purpose because it is also $\alpha$ granule specific and shares $\sim 50 \%$ sequence homology with the PF4 protein. As shown in Fig. $1 A, \beta$-TG not only failed to inhibit megakaryocyte colony formation, but in two of three studies resulted in increases in colony formation that approached statistical significance $(P=0.06)$ (Fig. $1 A)$.

Effect of synthetic COOH-terminal PF4, and $\beta$-TG peptides on megakaryocyte colony formation. To exclude the possibility that a minor, but highly active contaminant of the purified human PF4 preparations was responsible for megakaryocyte colony inhibition, we tested the ability of several synthetic peptides to reproduce the inhibitory effect observed with the native protein. Two synthetic PF4 peptides were used. One peptide consisted of last 13 amino acid residues from the carboxy terminus and was designated short peptide. The other consisted of the last 24 residues and was designated long peptide. In addition, a synthetic $\beta$-TG peptide consisting of the final 18 amino acid residues from the carboxy terminus was also tested as a control.

The results of four experiments with the synthetic $\mathrm{COOH}$ terminal PF4 peptides are shown in Table II. As indicated, the short and long peptides were tested in a dose-response manner at $2.5,25$, and $50 \mu \mathrm{g} / \mathrm{ml}$ concentrations. The short peptide demonstrated inhibitory activity in only one of the three studies performed, and this was at the highest concentration tested. In contrast, inhibitory activity was more consistently noted with the long peptide. In two of three experiments long peptide inhibited colony formation at $25 \mu \mathrm{g} / \mathrm{ml}$ concentration, and in four experiments at the $50-\mu \mathrm{g} / \mathrm{ml}$ concentration. At similar concentrations, the $\beta$-TG peptide had no effect on megakaryocyte colonies formed in comparison to control (data not shown). These results suggested that results with the purified protein were not due to artifact and that the carboxy-terminal domain of the PF4 protein contained at least part of the inhibitory activity noted in the above experiments.

Potency and lineage specificity of PF4-mediated inhibition. To determine the relative potency of PF4-mediated inhibition of megakaryocyte colony formation we next determined whether native PF4 $(25 \mu \mathrm{g} / \mathrm{ml})$ and long PF4 peptide $(25$ $\mu \mathrm{g} / \mathrm{ml}$ ) could still inhibit in vitro megakaryocytopoiesis in the presence of exogenous colony stimulators (Fig. $1 B$ ). rH IL 3 $(\sim 20 \mathrm{U} / \mathrm{ml})$, and $\mathrm{rH} \mathrm{GM}-\mathrm{CSF}(\sim 5 \mathrm{ng} / \mathrm{ml})$ were therefore added to the cultures in addition to the PF4 preparations. Three experiments were performed; one with native protein, and two with long peptide. In each, significant inhibition of colony formation was observed. The degree of inhibition in each was similar, being $55 \%$ with the native protein, and 71 and $49 \%$ with the long peptide (average $=58 \%$ ). The effect of highly purified $\beta$-TG on megakaryocyte colony formation was also assessed under these growth conditions. In contrast to the results with the PF4 preparations, and similar to the results in the basal cultures, no effect on colony formation was observed.

Finally, to determine lineage specificity of the PF4 effect, we tested the ability of purified human PF4 protein to inhibit CFU-E, and CFU-GM-derived colony formation. As shown in Fig. 2, no inhibition of erythroid colony forming units (CFUE) was noted at concentrations of PF4 that consistently inhibited megakaryocyte colony formation. Similarly, we observed no effect on CFU-GM-derived colony formation in any of the experiments performed, either in the absence or presence of exogenously added growth factors. In a typical result performed under the latter conditions, $246 \pm 55$ (mean \pm SD) colonies were enumerated in the control plates, whereas $262 \pm 28$ colonies were enumerated in plates containing $25 \mu \mathrm{g} / \mathrm{ml} \mathrm{na-}$ tive PF4.

Studies on the mechanism of PF4-induced inhibition of megakaryocytopoiesis. If one considers potential mechanisms for the observed decrement in megakaryocyte colony formation in the presence of PF4, the most proximate would include inhibition of progenitor cell proliferation, progenitor or precursor cell maturation, or both. We attempted to assess these 
Table II. Effect of Synthetic COOH-Terminal PF4 Peptides on Megakaryocyte Colony Formation

\begin{tabular}{|c|c|c|c|c|c|c|c|}
\hline \multirow[b]{2}{*}{ Study no. } & \multirow[b]{2}{*}{ Control (C) cells } & \multicolumn{3}{|c|}{ Short peptide (residues 58-70) } & \multicolumn{3}{|c|}{ Long peptide (residues $47-70$ ) } \\
\hline & & $2.5 \mu \mathrm{g} / \mathrm{ml}$ & $25 \mu \mathrm{g} / \mathrm{ml}$ & $50 \mu \mathrm{g} / \mathrm{ml}$ & $2.5 \mu \mathrm{g} / \mathrm{ml}$ & $25 \mu \mathrm{g} / \mathrm{ml}$ & $50 \mu \mathrm{g} / \mathrm{ml}$ \\
\hline 1 & $33 \pm 1^{*}$ & $31 \pm 5$ & $33 \pm 2$ & $28 \pm 4$ & $37 \pm 5$ & $\begin{array}{c}23 \pm 2 \\
(P=0.05)^{\ddagger}\end{array}$ & $\begin{array}{c}9 \pm 6 \\
(P=0.05)\end{array}$ \\
\hline 2 & $113 \pm 12$ & $157 \pm 12$ & $107 \pm 10$ & $94 \pm 8$ & $88 \pm 14$ & $144 \pm 17$ & $\begin{array}{c}50 \pm 26 \\
(P=0.05)\end{array}$ \\
\hline 3 & $7 \pm 1$ & $5 \pm 0$ & $-\S$ & $\begin{array}{c}1 \pm 0 \\
(P=0.01)\end{array}$ & $8 \pm 2$ & - & $\begin{array}{c}1 \pm 1 \\
(P=0.01)\end{array}$ \\
\hline 4 & $24 \pm 5$ & - & - & - & $18 \pm 4$ & $\begin{array}{c}10 \pm 2 \\
(P=0.03)\end{array}$ & $\begin{array}{c}10 \pm 1 \\
(P=0.02)\end{array}$ \\
\hline
\end{tabular}

Light-density marrow MNC were depleted of adherent monocyte-macrophages and T lymphocytes, and then cloned in plasma clot cultures as described in Methods. Short (13 amino acid residues) and long (24 amino acid residues) synthetic PF4 peptides were then added to the cultures in dose-response fashion and resulting megakaryocyte colonies enumerated as described. * Mean \pm SEM of megakaryocyte colonies enumerated in quadruplicate culture plates. ${ }^{\ddagger} P$ statistic in comparison to growth in control plates. ${ }^{\S}$ Not tested.

possibilities in several ways. First, to assess potential effects on progenitor cell proliferation under basal growth conditions, we enumerated the total numbers of cells making up each individual colony in 200 control colonies and in one hundred colonies cloned in plates containing long PF4 peptide. Control colonies were found to contain $6.1 \pm 3.0($ mean \pm SD) cells per colony, whereas colonies grown in the PF4 containing plates contained $4.2 \pm 1.6$ cells per colony. This difference was small, but of statistical significance $(P<0.001)$ (Table III). We then quantitated the number of large mature cells and small immature cells in these same colonies as an index of effect on cell

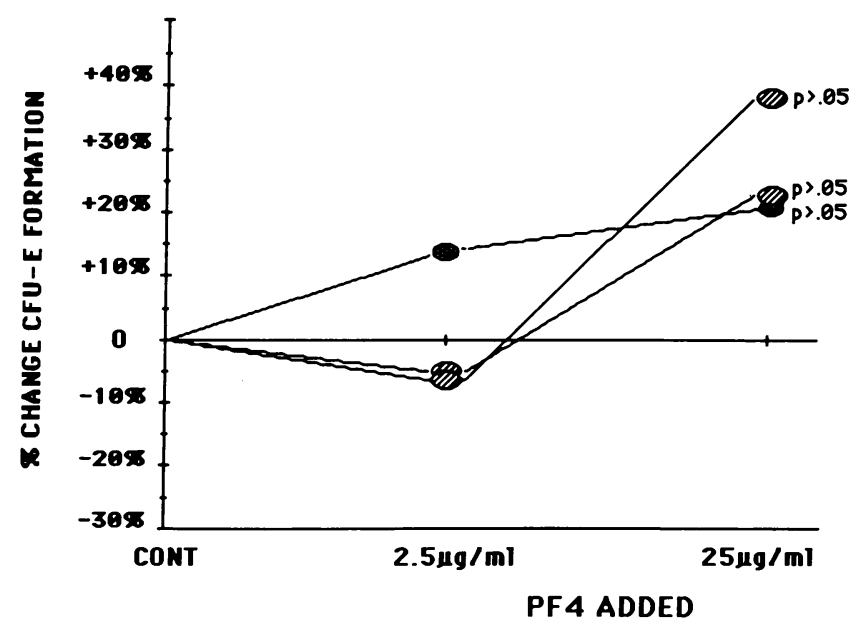

Figure 2. Effect of highly purified PF4 on clonogenicity of normal human CFU-E in plasma clot culture in the absence of accessory marrow immunocytes. Bone marrow MNC were isolated by density gradient sedimentation, and then depleted of adherent monocytemacrophages and lymphocytes as detailed in Methods. After $7 \mathrm{~d}$ in culture, plates were harvested and fixed. CFU-E were detected by benzidine staining as described in Methods. Results of three separate experiments, each performed in quadruplicate culture plates are shown. Control erythroid colony growth (per $5 \times 10^{5}$ target cells $/ \mathrm{ml}$ ) was $82 \pm 11$ colonies in one study stimulated by the addition of aplastic anemia serum; and 1,003 \pm 92 and $1,082 \pm 6$ in two studies stimulated with $5 \mathrm{U} / \mathrm{ml}$ of recombinant human erythropoietin (Amgen Corp., Thousand Oaks, CA). maturation (Table III). Control colonies were composed of $3.9 \pm 2.3$ large cells, whereas those arising in PF4 containing plates had $1.6 \pm 1.6$ large cells. This $59 \%$ reduction in large cells was highly significant $(P<0.001)$. In contrast, there were $2.1 \pm 2.1$ small cells in control colonies compared with $2.6 \pm 1.8$ in plates containing PF4. In aggregate, these results suggested that PF4 exerted a greater effect on megakaryocyte maturation, than on megakaryocyte progenitor cell proliferation.

Accordingly, we sought to determine directly if PF4 could inhibit a megakaryocyte function associated with increasing maturation. Coagulation cofactor V (FV) was chosen as a suitable marker because we have demonstrated that this protein is expressed only in more mature cells of the megakaryocyte lineage (37). Normal, mature human megakaryocytes were isolated from bone marrow by centrifugal elutriation, and suspended for up to $24 \mathrm{~h}$ in liquid cultures containing synthetic long PF4 peptide. The cells were then fixed as described above and probed for the expression of FV mRNA by the technique of in situ hybridization using a biotinylated cDNA probe. Results of a typical experiment are shown in a composite photomicrograph (Fig. $3, A-F$ ). Cells in $A$ were hybridized with a pBR322 probe and are unlabeled. In $B$, cells were probed with an insert for human $\beta$ actin and are strongly labeled. This

Table III. Effect of Long Synthetic COOH-Terminal PF4 Peptide on Megakaryocyte Colony Formation

\begin{tabular}{lcc}
\hline & $\begin{array}{c}\text { Control colonies } \\
(n=200)^{*}\end{array}$ & $\begin{array}{c}\text { Colonies cloned in PF4 } \\
(n=100)\end{array}$ \\
\hline Total cells/colony & $6.1 \pm 3.0^{\ddagger}$ & $4.2 \pm 1.6^{\S}$ \\
Large cells/colony & $3.9 \pm 2.3$ & $1.6 \pm 1.6^{\S}$ \\
Small cells/colony & $2.1 \pm 2.1$ & $2.6 \pm 1.8$
\end{tabular}

Marrow mononuclear cells were prepared and cultured as described in the legends for Tables I and II and in Methods. Long PF4 was added at a final concentration of $50 \mu \mathrm{g} / \mathrm{ml}$. Colonies were identified by indirect immunofluorescence and analyzed in situ at total magnifications of 100 and 400 .

* $n=$ total number of colonies examined.

$\ddagger$ Mean \pm SD of total cells enumerated.

${ }^{\S} P<0.001$

Platelet Factor 4 Inhibits Human Megakaryocytopoiesis 

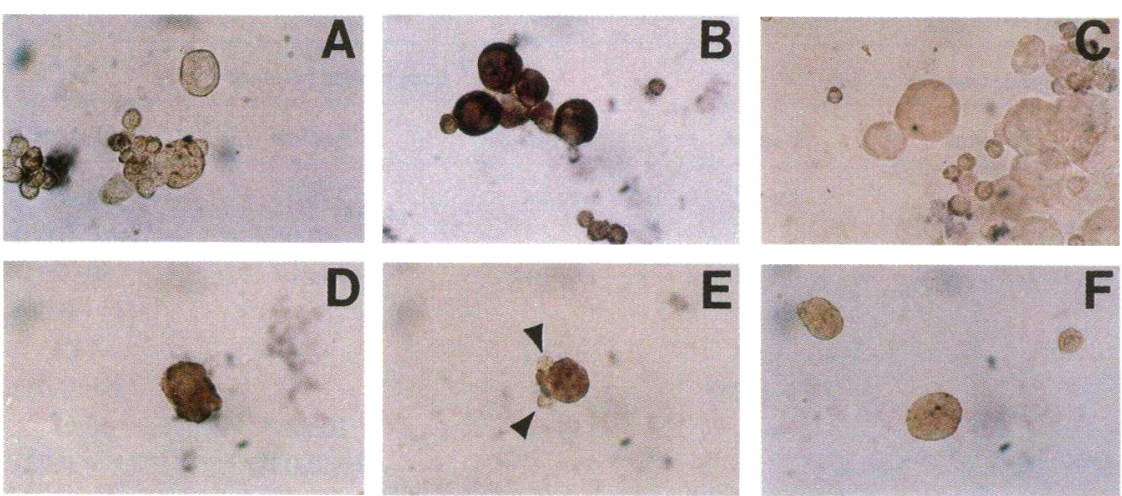

Figure 3. Effect of PF4 on expression of coagulation FV mRNA in human megakaryocytes. Composite photomicrograph of normal human megakaryocytes probed for expression of $\beta$ actin and coagulation FV mRNA by in situ hybridization with DNA probes labeled by random priming with biotin-11-dUTP. Megakaryocytes were separated from bone marrow by counterflow centrifugal elutriation, and then placed in suspension cultures for 16-18 $\mathrm{h}$ in medium containing either a synthetic long PF4 peptide (100 $\mu \mathrm{g} / \mathrm{ml})$ or no PF4. Hybridization was performed as detailed in Methods and is indicated by the appearance of purplebrown precipitate over the cytoplasm of the

cell. The greater the amount of hybridization that occurs, the darker and denser the precipitate that forms. Appearance of cells post hybridization with probes for pBR322 and $\beta$-actin is shown in $A$ and $B$, respectively. $C$ demonstrates the appearance of cells pretreated with RNase A $(500 \mu \mathrm{g} / \mathrm{ml})$ for $\sim 1 \mathrm{~h}$ before hybridization with $\beta$ actin probe. ( $D$ and $E)$ Representative color development for megakaryocytes hybridized with FV probe. (Arrows) Two small, unlabeled mononuclear cells on side of megakaryocyte in $D$. $(F)$ Representative color occurring in megakaryocytes hybridized with FV probe after 16-18-h incubation in PF4. Identical results were obtained by using concentrations of PF4 as low as $100 \mathrm{ng} / \mathrm{ml}$. At a PF4 concentration of $20 \mathrm{ng} / \mathrm{ml}, \mathrm{FV}$ mRNA levels were unchanged compared with controls.

signal is essentially eliminated by pretreating cells with RNase $(500 \mu \mathrm{g} / \mathrm{ml})$ before hybridization as shown in $C . D$ and $E$ show typical signal achieved after hybridization with the FV cDNA probe. $F$ demonstrates the marked reduction in signal noted after incubation in $100 \mu \mathrm{g} / \mathrm{ml} \mathrm{PF} 4$ for $16-18 \mathrm{~h}$. Comparable decreases in FV mRNA were found when megakaryocytes were exposed to concentrations of long PF4 peptide as low as $100 \mathrm{ng} / \mathrm{ml}$. At $20 \mathrm{ng} / \mathrm{ml}$ the effect was no longer detectable. In contrast to these results, the synthetic $\beta$-TG peptide caused no discernible decrease in FV mRNA levels at concentrations up to $10 \mu \mathrm{g} / \mathrm{ml}$, a dose well in excess of that at which long PF4 peptide exerted significant effects on FV mRNA levels.

To objectify our results, accumulation of indicator dye in megakaryocytes posthybridization was semiquantitated by microspectrophotometry (see Methods). It should be emphasized that since the photometer is not as sensitive to grey scale changes within a color family as it is to black and white, differences recorded are underestimates of true changes observed (see Fig. 3).

Light transmission through mononuclear cells was found to be quite constant after hybridization with the FV probe, regardless of the conditions under which the cells were cultured. MNC in the control suspension cultures $(n=228)$ were found to allow $73.2 \pm 7.5 \%$ light transmission (100\% maximum), whereas similar cells exposed to $100 \mu \mathrm{g} / \mathrm{ml}$ of synthetic PF4 peptide permitted $72.8 \pm 7.8 \%$ light transmission $(n$ $=216)$. These differences were of no statistical significance $(P$ $=0.559$ ). In contrast, light transmission through megakaryocytes incubated in PF4 was $64.4 \pm 8.4 \%$ posthybridization ( $n$ $=292$ ) with the FV cDNA probe, versus $58 \pm 9.5 \%$ in the control cells $(n=298)$. This difference, while small in absolute terms, was highly significant $(P<0.001)$. If the change in light transmission in these groups is compared with that permitted by the unlabeled MNC it is calculated that control megakaryocytes had $60 \%$ greater dye accumulation than cells incubated in PF4 [73-64\% $=\Delta 9 ; 73-58 \%=\Delta 15 ; 9 / 15=0.6]$. These data are indicative of a highly significant decline in FV mRNA after exposure to PF4. It is unlikely that this decrement was due to a toxic effect of the PF4 preparation because similarly prepared $\mathrm{COOH}$-terminal $\beta$-TG peptide had no effect on FV mRNA levels, and the c-myc message, which is known to have a very short half-life (55), was still highly expressed in cells cultured under both control and experimental conditions (data not shown).

Potential molecular mechanism(s) for the biological effects of PF4 described above were explored by examining the effect of PF4 on expression of genes whose products have been linked to cell growth and differentiation. The genes chosen for analysis were $\mathrm{p} 53$, histone $\mathrm{H} 3, \mathrm{c}-m y c$, and c-myb. Histone $\mathrm{H} 3$ and p53 are known to be expressed in greater amounts in proliferating as opposed to quiescent cells (40). Expression of c- $m y c$ and c- $m y b$ have also been related to cell growth, and maturation $(56,57)$. The human leukemia cell line HEL was used as an indicator system for these studies as it is not currently possible to obtain sufficient numbers of enriched megakaryocyte progenitor cells to conduct this type of experiment. HEL cells are known to express several phenotypic markers characteristic of early megakaryocytes such as platelet glycoproteins and platelet-derived growth factor (PDGF) (58) and were therefore used as a model for studying early megakaryocyte proliferation and maturation related events.

As shown in Fig. 4, when HEL cells in log phase growth are exposed to high concentrations of PF4, there was no appreciable change in expression of histone $\mathrm{H} 3$ at any of the times tested when compared with time 0 . Similarly, there is clearly no downregulation of $\mathrm{p} 53$, and in fact the autoradiogram suggests a slight induction in the level of p53 expression. These results are concordant with the colony data described above and again suggest that PF4 exerts minimal antiproliferative effects on cells it contacts.

Expression levels of the protooncogenes c-myc and c-myb in the presence or absence of PF4 are shown in Figs. 5 and 6. Exposure of HEL cells in $\log$ phase growth to $50 \mu \mathrm{g} / \mathrm{ml}$ of purified PF4 protein was associated with a clearly identifiable increase in c-myc expression at both 2 and $12 \mathrm{~h}$ in comparison to the time 0 control (Fig. 5). No change in expression of these genes over $24 \mathrm{~h}$ was observed in HEL cells not exposed to PF4. Exposure of HEL cells to the $100 \mu \mathrm{g} / \mathrm{ml}$ of long synthetic PF4 peptide was also found to effect protooncogene expression, resulting in a two- to fourfold increase in c- $m y b$ expression at 2 


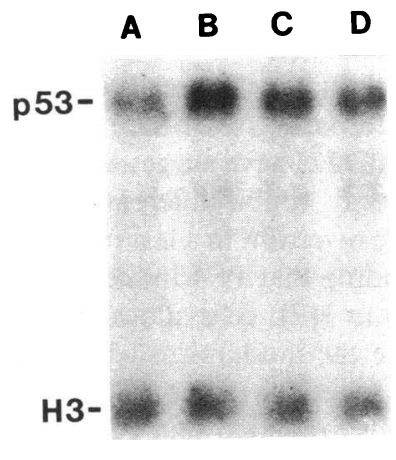

Figure 4. Effect of PF4 on expression of $\mathrm{p} 53$ and histone $\mathrm{H} 3$ by HEL cells. Northern blot analysis of total cellular RNA extracted from HEL cells unexposed to PF4 (control, lane $A$ ), or after incubation in suspension culture in the presence of purified PF4 (50 $\mu \mathrm{g} / \mathrm{ml}$ ) for 2 (lane $B$ ), 12 (lane $C$ ), or $24 \mathrm{~h}$ (lane $D$ ). Equal amounts of RNA ( $\sim 15 \mu \mathrm{g} /$ lane $)$ were size fractionated in $1.2 \%$ agarose gel containing $6.6 \%$ formaldehyde, blotted to nitrocellulose as described, and then hybridized to ${ }^{32} \mathrm{P}$-labeled DNA probes for $\mathrm{p} 53$ and histone $\mathrm{H} 3$.

and 12 hours (Fig. 6). In contrast, $\beta_{2}$-microglobulin gene expression was unaffected at these same time points.

\section{Discussion}

We initially became interested in PF4 when Katz et al. reported that platelet alpha granule releaseates could augment the immune response of SJL mice to foreign antigens, and reverse lymphoma or allogeneic $\mathrm{T}$ lymphocyte-induced immunosuppression $(33,34)$. The responsible factor was subsequently identified as PF4. Because several groups have reported that helper $\mathrm{T}$ lymphocytes can augment megakaryocytopoiesis $(59,60)$ the addition of PF4 to our cultures might have augmented colony formation. Alternatively, because our own studies with $\mathrm{T}$ lymphocytes (and subsets) suggest that non-activated cells have little impact on megakaryocytopoiesis (12), we believed that no change in colony formation might also be observed. Therefore, we were surprised that PF4 inhibited megakaryocyte colony formation. Further experiments suggested that the suppressive effect observed did not require the cooperation of $\mathrm{T}$ lymphocytes (Table I), and was likely due to a direct effect on cells of the megakaryocyte lineage (Fig. 1). Because PF4 is synthesized by megakaryocytes, and binds to platelets (and presumably megakaryocytes) in a reversible and saturable manner $\left(K_{d} \sim 2.7 \times 10^{-8} \mathrm{M}\right)(27)$, it fulfills all criteria as a genuine autocrine regulator (61). In support of this concept, PF4 does not bind to erythrocytes (31) and has no effect on erythroid colony formation (Fig. 2). These results contrast in an important way with the more general inhibition of hematopoiesis reported to be caused by TGF- $\beta$ (18).

The possibility that residual impurities, or another contaminating platelet protein in the PF4 preparation might have been responsible for the diminution in colony formation was

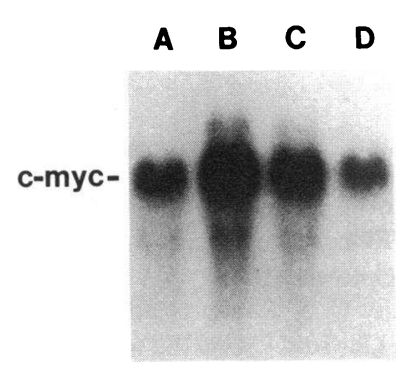

Figure 5. Effect of PF4 on c-myc expression in HEL cells. Nitrocellulose filter hybridized to produce autoradiogram shown in Fig. 4 was extensively washed and then rehybridized with ${ }^{32} \mathrm{P}$-labeled DNA probe for human c-myc. Lane $A$, time 0; lane $B, 2$-h incubation in PF4; lane $C$, 12-h incubation in PF4; lane $D, 24-\mathrm{h}$ incubation in PF4.

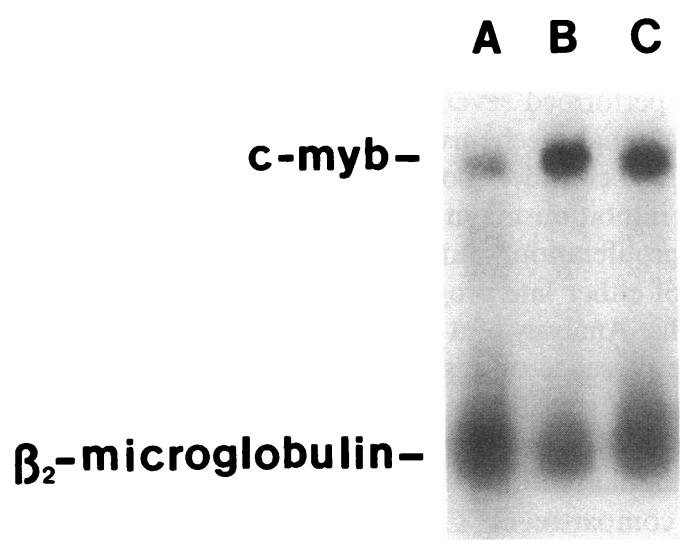

Figure 6. Effect of synthetic PF4 long peptide on c-myb, and $\beta_{2}$-microglobulin expression in HEL cells. HEL cells were incubated in $100 \mu \mathrm{g} / \mathrm{ml}$ of long PF4 peptide, and total cellular RNA extracted after 0-, 2-, and 12-h exposures to PF4. Equal amounts of RNA $(\sim 15 \mu \mathrm{g}$ lane) were size fractionated in $1.2 \%$ agarose gel containing $6.6 \%$ formaldehyde, blotted to nitrocellulose as described, and then hybridized to ${ }^{32} \mathrm{P}$-labeled DNA probes for c- $m y b$ and $\beta_{2}$-microglobulin. Lane $A$, time 0; lane $B$, 2-h incubation in PF4; lane $C, 12$-h incubation in PF4.

explored by testing two synthetic $\mathrm{COOH}$-terminal PF4 peptides in an identical bioassay. A short peptide consisting of the last thirteen amino acids of the carboxy terminus appeared to have less consistent colony inhibitory activity than a long peptide consisting of the last 24 amino acids of this region (Table II). The latter significantly $(P<0.05)$ inhibited colony formation in all four experiments performed. The degree of inhibition varied but was always $>50 \%$ with a mean $( \pm \mathrm{SD})$ of $69 \pm 14 \%$.

To understand why colony inhibition varied with the PF4 preparation used, we deduced the predicted structure of the PF4 peptides used. A Chou and Fasman type analysis was used (62), with the constraint that the total number of residues in each configuration agree with the totals deduced from the observed circular dichroism spectra (63). Comparison of the synthetic peptides' sequences suggests that the long peptide may contain two $\beta$ pleated sheets, whereas the short peptide contains only one stretch of $\beta$ pleated sheet. The long peptide also contains a cysteine residue at position 52 that could allow for the formation of dimers, whereas the absence of this residue in the short peptide suggests that if may exist in monomeric form only. Recent nuclear magnetic resonance data from our laboratory also suggest that the long peptide and the native protein share some helical structure in the $\mathrm{COOH}$-terminal domain (64). Finally, when native PF4, and the long and short peptides are adsorbed onto a heparin-agarose column, they are eluted with $1.2,0.5$, and $0.2 \mathrm{M} \mathrm{NaCl}$ concentrations, respectively, thereby demonstrating differential heparin binding avidity. These differences may at least partially explain why the shorter peptide had less detectable colony inhibitory activity. Regardless, these data suggest that the inhibitory effect may be localizable to the carboxy-terminal domain of PF4. Whether other portions of the molecule have similar or greater activity remains to be determined. They also suggest that biologic effects discerned are not due to the strong positive charge of the PF4 molecule. If charge alone were responsible for the effects observed, then one would have seen greater inhibition with the 
synthetic peptides, as they bear much greater charge than the purified native protein.

We then performed several types of analysis designed to determine potential mechanisms for the colony inhibitory effect. First, if one considers potential mechanisms of action of this protein, inhibition might be effected by suppressing progenitor cell proliferation, and/or by imposing a block in the maturation of either late progenitor, or early megakaryocyte precursor cells. Analysis of a total of three hundred colonies grown in the presence or absence of PF4 revealed a modest $(\sim 33 \%)$, though statistically significant decline in the total number of cells/colony in the presence of PF4 (Table III). This result suggested that PF4 had only minor effects on cells in the proliferative compartment. This interpretation was supported by the finding that, regardless of culture conditions, the numbers of small, immature cells per colony did not appear to differ in a meaningful way (Table III). Because these small cells either include, or are the immediate progeny of, cells in the proliferative compartment, one would have expected differences in their number had PF4 exerted an effect at this level. Further, when we compared the numbers of large, mature cells per colony, PF4 containing plates had an easily discerned decrease $(\sim 60 \%, P<0.001)$ in these cells when compared with controls. Finally, if PF4 acted significantly on proliferating cells we would have expected an even greater decrease in colony numbers when IL 3 and GM-CSF were added to the cultures, a finding which was not observed (Fig. $1 B$ ). In aggregate, these data led to the hypothesis that PF4 exerted much more profound effects on megakaryocyte maturation than on progenitor cell proliferation, though we cannot exclude effects on an as yet identified subpopulation of megakaryocyte progenitor cells. Because the numbers of small cells in colonies is unaffected, whereas the number of mature large cells per colony is significantly diminished, these data suggest that a cell transitional between these types is the likely target of the PF4 inhibitory effect.

Several experimental strategies were then employed to corroborate the conclusions drawn from the cell culture experiments. First, we used the human erythroleukemia cell line HEL as a model system for testing the antiproliferative effects of PF4 on a primitive, highly proliferative cell with megakaryocytic properties. As noted in Results (Fig. 4), exposure to PF4 did not appear to effect the expression of the cell cycle-dependent genes $\mathrm{p} 53$ or histone $\mathrm{H} 3$ as determined by Northern analysis. In addition, the doubling time of the HEL cells was not effected by adding PF4 to the culture medium (data not shown). In contrast, by using the technique of in situ hybridization we were able to demonstrate that mRNA levels of the maturation related FV gene could be downregulated by exposure to synthetic $\mathrm{COOH}$-terminal long PF4 peptide at concentrations as low as $100 \mathrm{ng} / \mathrm{ml}$. Both trypan blue exclusion, maintenance of the short-lived c-myc message in treated cells, and failure to achieve a similar result with a $\beta$-TG synthetic peptide all strongly suggested that this effect was not due to PF4-induced cell toxicity.

In hematopoietic cells, control of cell proliferation and maturation are often linked to the expression of the growthregulated genes $c-m y c$ and $c-m y b$. A large number of investigations have demonstrated that as these cells differentiate the levels of expression of both genes decline (65-67). In addition, Coppola and Cole (68), Dmitrovsky et al. (69), and Prochownik and Kukowska (70), have demonstrated that transfection of mouse erythroleukemia cells with plasmid constructs containing highly expressible c-myc inserts leads to overexpression of the exogenous c- $m y c$ and an inability of these cells to undergo erythroid differentiation in response to DMSO. Similarly, Beug et al. (71) and Ness et al. (72) have suggested that overexpression of v-myb may not only inhibit differentiation but in the appropriate system, cause reversion to a less mature phenotype (71). Therefore, our finding that PF4 induces expression of both c-myc and c-myb in HEL cells allows us to cautiously suggest that this may be the mechanism whereby PF4 inhibits maturation of human megakaryocytes.

Recently, Mitjavila et al. (19) also reported that PF4 can exert some inhibition on in vitro megakaryocytopoiesis, though higher PF4 concentrations than we used were required. These data, in conjunction with our own, strongly suggest that PF4 can modulate human megakaryocytopoiesis in vitro. Although it must be stated clearly that the physiologic relevance of our findings remain undetermined, several considerations lead us to postulate that the findings reported may be of biological import. First, it is known that platelet (megakaryocyte) concentrations of PF4 are extraordinarily high in relationship to plasma (PF4 platelet plasma distribution index value $>20,000$ [25]), and that microgram concentrations of PF4 are achievable in serum (73). High PF4 concentrations resulting from platelet release and/or megakaryocyte degeneration might be achievable then in the marrow sinusoids that do not freely communicate with plasma. Second, platelets may not internalize or shed surface PF4-receptor complexes (32). This circumstance might provide a mechanism for concentrating sufficient PF4 on the cell surface to exert the putative biological effect. Alternatively, internally synthesized PF4 might stimulate an intracellular portion of the PF4 receptor in a manner similar to that described for PDGF and its receptor (74). Finally, FV mRNA levels are decreased by nanogram range doses of material. Accordingly, we hypothesize that PF4 may function as a negative autocrine regulator of human megakaryocytopoiesis. In this regard, it is again of interest that we observed less colony inhibition in cultures containing exogenously added growth factors than in those designed to emulate basal marrow growth conditions. This observation could have physiological relevance in that it suggests a potential mechanism for overriding PF4-induced inhibition. Such a phenomenon would be of great importance in situations were ongoing platelet destruction (and release of PF4) would necessarily require compensatory increases in platelet production. Alternatively, because it is known that prolonged exposure to a ligand can lead to downmodulation of receptor (75) escape from PF4 mediated inhibition might also occur in this manner in the in vivo situation just referred to. All these considerations lead us to further hypothesize that PF4 mediated inhibition may be of greater physiologic significance under homeostatic conditions. Studies aimed at providing more definitive proof of these postulates are presently ongoing in our laboratory.

\section{Acknowledgments}

We thank Dr. John C. Holt, Macromolecular Analysis and Synthesis Laboratory, Temple University School of Medicine, for his help in predicting the structure of synthetic PF4 peptides. The editorial assistance of E. R. Bien is also gratefully acknowledged.

This work was supported in part by U. S. Public Health Service grants CA-36896, CA-01324 to A. M. Gewirtz, CA-46782 to B. Cala- 
bretta, and HL-36579 to S. Niewiarowski; Grants-In-Aid from the Delaware and Southeast Pennsylvania Chapters of the American Heart Association to A. M. Gewirtz, and the Leukemia Research Foundation, Chicago, IL to B. Calabretta. Dr. Gewirtz is the recipient of a Research Career Development Award from the National Cancer Institute.

\section{References}

1. Gewirtz, A. M. 1986. Human megakaryocytopoiesis. Semin. Hematol. 23:27-42.

2. Hoffman, R., H. H. Yang, E. Bruno, and J. Straneva. 1985 Purification and partial characterization of a megakaryocyte colonystimulating factor from human plasma. J. Clin. Invest. 75:1174-1182.

3. Kaushansky, K., P. O’Hara, K. Berner, G. M. Segal, F. S. Hagen, and J. W. Adamson. 1986. Genomic cloning, characterization and multilineage growth-promoting activity of human granulocyte macrophage colony-stimulating factor. Proc. Natl. Acad. Sci. USA. 83:31013105 .

4. Leary, A. G., Y. C. Yang, S. C. Clark, J. C. Gasson, D. W. Golde, and M. Ogawa. 1987. Recombinant gibbon Interleukin 3 supports formation of human multilineage colonies and blast cell colonies in culture: comparison with recombinant human granulocyte-macrophage colony stimulating factor. Blood. 70:1343-1348.

5. McDonald, T. P., M. Cottrel, and R. D. Clift. 1985. Studies on the purification of thrombopoietin from kidney cell culture medium. J. Lab. Clin. Med. 106:162-174.

6. Hill, R., and J. Levin. 1986. Partial purification of thrombopoietin using lectin chromatography. Exp. Hematol. 14:752-759.

7. Greenberg, S. M., D. J. Kuter, and R. D. Rosenberg. 1987. In vitro stimulation of megakaryocyte maturation by megakaryocyte stimulatory factor. J. Biol. Chem. 262:3269-3277.

8. Tayrien, G., and R. D. Rosenberg. 1987. Purification and properties of a megakaryocyte stimulatory factor present both in the serum-free conditioned medium of human embryonic kidney cells and in thrombocytopenic plasma. J. Biol. Chem. 262:3262-3268.

9. Ishibashi, T., S. A. Kozial, and S. A. Burstein. 1987. Human recombinant erythropoietin promotes differentiation of murine megakaryocytes in vitro. J. Clin. Invest. 79:286-289.

10. Nagasawa, T., T. Sakuri, H. Kashiwagi, and T. Abe. 1986. Cell-mediated amegakaryocytic thrombocytopenia associated with systemic lupus erythematosus. Blood. 67:479-483.

11. Gewirtz, A. M., M. C. Sacchetti, R. Bien, and W. E. Barry 1986. Cell-mediated suppression of megakaryocytopoiesis in acquired amegakaryocytic thrombocytopenic purpura. Blood. 68:619-626.

12. Gewirtz, A. M., W. Y. Xu, and K. F. Mangan. 1987. Role of natural killer cells, in comparison with $\mathrm{T}$ lymphocytes and monocytes, in the regulation of normal human megakaryocytopoiesis in vitro. $J$. Immunol. 139:2915-2925.

13. Vainchenker, W., J. Chapman, J. F. Deschamps, G. Vinci, J. Bouguet, M. Titeux, and J. Breton-Gorius. 1982. Normal human serum contains a factor(s) capable of inhibiting megakaryocyte colony formation. Exp. Hematol. 10:650-660.

14. Messner, H. A., N. Jamal, and C. Izaquirre. 1982. The growth of large megakaryocyte colonies from human bone marrow. J. Cell. Physiol. (Suppl.)1:45-51.

15. Kimura, H., S. A. Burstein, D. Thorning, J. S. Powell, L. A. Harker, P. J. Fialkow, and J. W. Adamson. 1984. Human megakaryocytic progenitors (CFU-M) assayed in methylcellulose: physical characteristics and requirements for growth. J. Cell. Physiol. 118:87-94.

16. Gewirtz, A. M., and M. K. Sacchetti. 1986. Autoregulation of human megakaryocytopoiesis in vitro. Blood. 68(Suppl. 1):158a. (Abstr.)

17. Gewirtz, A. M., and R. Hoffman. 1986. Transitory hypomegakaryocytic thrombocytopenia: aetiological association with ethanol abuse and implications regarding regulation of human megakaryocytopoiesis. Br. J. Haematol. 62:333-344.
18. Ishibashi, T., S. L. Miller, and S. A. Burstein. 1987. Type $\beta$ transforming growth factor is a potent direct inhibitor of murine megakaryocytopoiesis in vitro. Blood. 69:1737-1741.

19. Mitjavila, M. T., G. Vinci, J. L. Villeval, N. Kieffer, A. Henri, U. Testa, J. Breton-Gorius, and W. Vainchenker. 1988. Human platelet alpha granules contain a nonspecific inhibitor of megakaryocyte colony formation: its relationship to type $\beta$ transforming growth factor (TGF-ß). J. Cell. Physiol. 134:93-100.

20. Solberg, L. A., R. F. Tucker, B. W. Grant, K. G. Mann, and H. L. Moses. 1987. In The Inhibitors of Hematopoiesis. A. Najman, M. Guyon, N. C. Gorin, and J. Y. Mary, editors. John Libbey, Montrose, France. 111-132.

21. Dessypris, E. N., J. H. Gleaton, S. T. Sawyer, and O. L. Armstrong. 1987. Suppression of maturation of megakaryocyte colony forming unit in vitro by a platelet-released glycoprotein. J. Cell. Physiol. 130:361-368.

22. Deuel, T. F., P. S. Keim, M. Farmer, and R. L. Heinrikson. 1977. Human platelet factor 4: complete amino acid sequence. Proc. Natl. Acad. Sci. USA. 74:2256-2258.

23. Hermodson, M., G. Schmer, and K. Kurachi. 1977. Isolation, characterization, and primary amino acid sequence of human platelet factor 4. J. Biol. Chem. 252:6276-6279.

24. Barber, A. J., R. Kaser-Glanzmann, M. Jakabova, and E. F. Luscher. 1972. Characterization of a chondroitin 4-sulfate proteoglycan carrier for heparin neutralizing activity (platelet factor 4 ) released from human blood platelets. Biochim. Biophys. Acta. 286:312-329.

25. Rucinski, B., L. C. Knight, and S. Niewiarowski. 1986. Clearance of human platelet factor 4 by liver and kidney: its alteration by heparin. Am. J. Physiol. 251 (Heart Circ. Physiol. 20):H800-807.

26. Levine, S. P., and H. Wohl. 1981. Human platelet factor 4: Purification and characterization by affinity chromatography. J. Biol. Chem. 251:324-328.

27. Lonsky, S. A., and H. Wohl. 1981. Stimulation of human leukocyte elastase by platelet factor 4. J. Clin. Invest. 67:817-826.

28. Hiti-Harper, J., H. Wohl, and E. Harper. 1978. Platelet factor 4: an inhibitor of collagenase. Science (Wash. DC). 199:991-992.

29. Senior, R. M., G. L. Griffin, J. S. Huang, D. A. Walz, and T. F. Deul. 1981. Chemotactic activity of platelet alpha granule proteins for fibroblasts. J. Cell Biol. 96:382-385.

30. Loscalzo, J., B. Melnick, and R. I. Handin. 1985. The Interaction of platelet factor 4 and glycoaminoglycans. Arch. Biochem. Biophys. 240:446-455.

31. Osterman, D. G., G. L. Griffin, R. M. Senior, E. T. Kaiser, and T. F. Duel. 1982. The carboxyl-terminal tridecapeptide of platelet factor 4 is a potent chemotactic agent for monocytes. Biochem. Biophys. Res. Commun. 107:130-135.

32. Capitanio, A. M., S. Niewiarowski, B. Rucinski, G. P. Tuszynki, C. S. Cierniewski, D. Hershock, and E. Kornecki. 1985. Interaction of platelet factor 4 with human platelets. Biochim. Biophys. Acta. 839:161-173.

33. Katz, I. R., M. K. Hoffmann, M. B. Zucker, M. K. Bell, and G. J. Thorbecke. 1985. A platelet-derived immunoregulatory serum factor with T cell affinity. J. Immunol. 134:3199-3203.

34. Katz, I. R., G. J. Thorbecke, M. K. Bell, Z. Yin, D. Clarke, and M. B. Zucker. 1986. Protese-induced immunoregulatory activity of platelet factor 4. Proc. Natl. Acad. Sci. USA. 83:3491-3495.

35. Gewirtz, A. M., E. Bruno, J. Elwell, and R. Hoffman. 1983. In vitro studies of megakaryocytopoiesis in thrombocytotic disorders of man. Blood. 61:384-389.

36. Mazur, E. M., R. Hoffman, J. Chasis, S. Marchesi, and E. Bruno. 1981. Immunofluorescent identification of human megakaryocyte colonies using an antiplatelet glycoprotein antiserum. Blood. 57:277-286

37. Gewirtz, A., M. Keefer, K. Doshi, A. Annamali, H. C. Chiu, and R. W. Colman. 1986. Biology of human megakaryocyte factor V. Blood. 67:1639-1648.

38. Gewirtz, A. 1987. Recent methodologic advances in the study of human megakaryocyte development and function. In Pharmaco- 
logic Methods for the Investigation of Coagulation and Platelets. R. W. Colman and B. J. Smith, editors. Alan R. Liss, Inc., New York. 1-18.

39. Martin, P., and T. Papayannapoulou. 1982. HEL Cells: a new human erythroleukemia cell line with spontaneous and induced globin expression. Science (Wash. DC). 216:1233-1235.

40. Calabretta, B., L. Kaczmarek, L. Selleri, G. Torelli, P. M. L. Ming, S. C. Ming, and W. E. Mercer. 1986. Growth dependent expression of human p53 tumor antigen mRNA in normal and neoplastic cells. Cancer Res. 46:5738-5742.

41. Thomas, P. S. 1980. Hybridization of denatured RNA and small DNA fragments transferred to nitrocellulose. Proc. Natl. Acad. Sci. USA. 77:5201-5205.

42. Feinberg, A. P., and B. Vogelstein. 1984. A technique for radiolabelling DNA restriction endonuclease fragments to high specific activity. Ann. Biochem. 137:266-267.

43. Wahl, G. M., M. Stern, and G. M. Stark. 1979. Efficient transfer of large DNA fragments from agarose gels to diazobenzyloxymethyl-paper and rapid hybridization by using dextran sulfate. Proc. Natl. Acad. Sci. USA. 76:3683-3687.

44. Brigati, D. J., D. Myerson, J. J. Leary, B. Spalholz, S. Z. Travis, C. K. Y. Fong, G. D. Hsuing, and D. C. Ward. 1983. Detection of viral genomes in cultured cells and paraffin-embedded tissue sections using biotin-labeled hybridization probes. Virology. 126:32-50.

45. Lum, J. B. 1986. Visualization of mRNA transcription of specific genes in human cells and tissues using in situ hybridization. Biotechniques. 4:32-39.

46. Singer, R. H., J. B. Lawrence, and C. Villnave. 1986. Optimization of in situ hybridization using isotopic and non-isotopic detection methods. Biotechniques. 4:230-250.

47. Kane, W. H., and E. Davie. 1986. Cloning of cDNA coding for human factor $\mathrm{V}$, a blood coagulation factor homologous to factor VIII of ceruloplasmin. Proc. Natl. Acad. Sci. USA. 83:6800-6804.

48. Sina, F., A. Lichtler, F. Marashi, R. Rickles, T. van Dyke, S. Clark, J. Wells, G. Stein, and J. Stein. 1982. Organization of human histone genes. Proc. Natl. Acad. Sci. USA. 79:1795-1799.

49. Watt, R., W. Stanton, K. Marcu, R. Gallo, C. Croce, and G. Rovera. 1983. Nucleotide sequence of cloned cDNA of human c-myc oncogene. Nature (Lond.). 303:725-728.

50. Suggs, S. V., B. R. Wallace, T. Hirose, E. H. Kuwashima, and K. Itakura. 1982. Use of synthetic oligonucleotides as hybridization probes: isolation of cloned cDNA sequence for human $\beta 2$-microglobulin. Proc. Natl. Acad. Sci. USA. 78:6613-6617.

51. Zakut-Houri, R., B. Beinz-Tadmor, D. Givol, and M. Oren 1985. Human p53 cellular tumor antigen: cDNA sequence and expression in COS cells. EMBO (Eur. Mol. Biol. Organ.) J. 4:1251-1255.

52. Gunning, R., P. Ponte, H. Okayama, J. Engel, H. Blau, and L. Kedes. 1983. Isolation and characterization of full-length cDNA clones for human $\alpha-, \beta$-, and $\gamma$-Actin mRNA: skeletal but not cytoplasmic actins have an amino-terminal cysteine that is subsequently removed. Mol. Cell. Biol. 3:787-795.

53. Majello, B., L. C. Kenyon, and R. Dalla-Favera. 1986. Human c- $m y b$ proto-oncogene: nucleotide sequence of cDNA and organization of the genomic locus. Proc. Natl. Acad. Sci. USA. 83:9636-9640.

54. Rucinski, B., S. Niewiarowski, P. James, D. A. Walz, and A. Budzynski. 1979. Antiheparin proteins secreted by human platelets. Purification, characterization and radioimmunoassay. Blood. 53:4762.

55. Dani, C., M. Mechti, M. Piechaczyk, B. Lebleu, P. Jeunteur, and J. M. Blanchard. 1984. Extreme instability of myc mRNA in normal and transformed human cells. Proc. Natl. Acad. Sci. USA 81:7046-7080.

56. Kelly, K., H. B. Cochran, C. D. Stiles, and P. Leder. 1983. Cell-specific regulation of the c-myc gene by lymphocyte mitogens and platelet-derived growth factor. Cell. 35:603-610.
57. Torelli, G., L. Selleri, A. Donelli, S. Ferreri, G. Emilia, D. Venturelli, L. Moretti, and U. Torelli. 1985. Activation of c-myb expression by phytohemagglutinin stimulation in normal human $\mathrm{T}$ lymphocytes. Mol. Cell. Biol. 5:2874-2877.

58. Papayannapoulou, T., E. Raines, S. Collins, B. Nakamoto, M Tweeddale, and R. J. Ross. Constitutive and inducible secretion of platelet-derived growth factor analogs by human leukemic cell lines coexpressing erythroid and megakaryocytic markers. J. Clin. Invest. 79:859-866

59. Geissler, D., L. Lu, E. Bruno, H. H. Yang, H. Broxmeyer, and R. Hoffman. 1986. The Influence of $T$ lymphocyte subsets and humoral factors on colony formation by human bone marrow and blood megakaryocyte progenitor cells in vitro. J. Immunol. 137:2508-2513.

60. Kanz, L., G. W. Lohr, and A. A. Fauser. 1986. Lymphokine(s) from isolated $\mathrm{T}$ lymphocyte subpopulations support multilineage hematopoietic colony and megakaryocytic colony formation. Blood. 68:991-995.

61. Sporn, M. B., and A. B. Roberts. 1985. Autocrine growth factors and cancer. Nature (Lond.). 313:745-747.

62. Chou, P. Y., and G. D. Fasman. 1978. Empirical predictions of protein conformation. Annu. Rev. Biochem. 47:251-276.

63. Holt, J. C., M. Kloczewiak, D. A. Walz, B. Rucinski, and S. Niewiarowski. 1981. Relation of heparin binding and conformation in PF4 and LA-PF4 (BTG). Thromb. Haemost. 46:204. (Abstr.)

64. Rucinski, B., S. Niewiarowski, M. Strzyzweski, J. C. Holt, and K. Mayo. 1988. Structural requirements for the expression of platelet factor 4 and its clearance from the circulation. Blood. 72(Suppl. 1):1255. (Abstr.)

65. Westin, E. H., R. C. Gallo, S. K. Azya, A. Eva, L. M. Souza, A. M. Baluda, S. A. Aaronson, and F. Wong-Staal. 1982. Differential expression of the amv gene in human hematapoietic cells. Proc. Natl. Acad. Sci. USA. 79:2194-2198.

66. Lachman, H., and A. I. Skoultchi. 1984. Expression of c-myc changes during differentiation of mouse erythroleukaemia cells. $\mathrm{Na}$ ture (Lond.). 310:592-594.

67. Gowda, S. D., R. D. Koler, and G. C. Bagby. 1986. Regulation of c-myc expression during growth and differentiation of normal and leukemic human myeloid progenitor cells. J. Clin. Invest. 77:271-278.

68. Coppola, J. A., and M. D. Cole. 1986. Constitutive c-myc oncogene expression blocks mouse erythroleukaemia cell differentiation but not commitment. Nature (Lond.). 320:760-763.

69. Dmitrovsky, E., W. M. Kuehl, G. E. Hollis, I. R. Kirsh, T. P. Bender, and S. Segal. 1986. Expression of a transfected human c-myc oncogene inhibits differentiation of a mouse erythroleukaemia cell line. Nature (Lond.). 320:748-750.

70. Prochownik, E., and J. Kukowska. 1986. Deregulated expression of c-myc by murine erythroleukaemia cells prevents differentiation. Nature (Lond.). 322:848-850.

71. Beug, H., P. A. Blundell, and T. Graf. 1987. Reversibility of differentiation and proliferative capacity in avian myelomonocytic cells transformed by tsE26 leukemai virus. Gene Dev. 1:277-286.

72. Ness, S. A., H. Beug, and T. Graf. 1987. v-myb dominance over v-myc in doubly transformed chick myelomonocytic cells. Cell. 51:41-50.

73. Files, J. C., T. W. Malpass, E. S. Yee, J. L. Ritchie, and L. A. Harker. 1981. Studies of human platelet $\alpha$-granule release in vivo. Blood. 58:607-618.

74. Keating, M. T., and L. T. Williams. 1988. Autocrine stimulation of intracellular PDGF receptors in v-sis-transformed cells. Science (Wash. DC). 239:914-916.

75. Heldin, C. H., B. Westermark, and A. Wasteson. 1979. Desensitization of cultured glial cells to epidermal growth factor by receptor down regulation. Nature (Lond.). 282:419-420. 